\title{
Die voorsienigheidsleer van Calvyn: Uit sy debatte
}

\author{
Author: \\ Morné Diedericks ${ }^{1}$ \\ Affiliation: \\ ${ }^{1}$ Education, Academic \\ and Reformatory Training \\ Studies (AROS), Pretoria, \\ South Africa \\ Correspondence to: \\ Morné Diedericks \\ Email: \\ morne.diedericks@aros. \\ ac.za \\ Postal address: \\ PO Box 31120, Totiusdal \\ 0134, South Africa \\ Dates: \\ Received: 25 Sept. 2013 \\ Accepted: 02 May 2014 \\ Published: 12 Sept. 2014 \\ How to cite this article: \\ Diedericks, M., 2014, 'Die \\ voorsienigheidsleer van \\ Calvyn: Uit sy debatte', \\ Koers - Bulletin for Christian \\ Scholarship 79(4), Art. \\ \#2149, 9 pages. http:// \\ dx.doi.org/10.4102/koers. \\ v79i4.2149 \\ Copyright: \\ (C) 2014. The Authors. \\ Licensee: AOSIS \\ OpenJournals. This work \\ is licensed under the \\ Creative Commons \\ Attribution License.
}

Calvyn se leer van God se voorsienigheid is ongetwyfeld een van die mees kontroversiële onderwerpe van sy teologie. Dit word duidelik in al die debatte waarin Calvyn sy leer oor die voorsienigheid moes verdedig, byvoorbeeld teen Pighius, Bolsec, Bullinger en Castellio. Vyfhonderd jaar later word Calvyn weer in die openbaar oor sy voorsienigheidsleer aangeval deur'n Suid-Afrikaanse teoloog, Adrio König. Calvyn se antwoord op Castellio in Die verborge voorsienigheid van God is duidelik nie deur König in ag geneem nie. In Calvyn se verdediging van sy voorsienigheidsleer verwerp hy nooit die soewereiniteit van God nie, maar gee ook nie vir God die skuld vir die kwaad nie - 'n beskuldiging wat Castellio en König teen Calvyn inbring. Die troos van God se voorsienigheid lê vir Calvyn juis daarin dat God alle dinge, ook teenspoed en verdrukking, deur sy verborge voorsienigheid beskik met die doel om sy kinders nader na Hom te lei.

Calvin's teaching on providence: From his debates. Calvin's teaching on God's providence is without doubt one of the most controversial subjects in his theology. This is clear in all the debates in which Calvin had to defend his teaching on providence, against, for example, Pighius, Bolsec, Bullinger and Castellio. Five hundred years later Calvin has again been publicly attacked on his teaching on providence by a South African theologian, Adrio König. König, however, did not consider Calvin's response to Castellio in The secret providence of God. In Calvin's defence of his teaching on providence he in no circumstances denies the sovereignty of God, but also does not give God the blame for any ills that might result - an accusation that Castellio and König levied against him. For Calvin, the consolation of God's providence rests in the fact that God ordains all things, including adversity and affliction, through his secret providence for the purpose of leading his children closer to him.

\section{Inleiding}

Adrio König is 'n Suid-Afrikaanse teoloog wat alreeds talle populêre boeke gepubliseer het, gereeld vir openbare koerante skryf en die meeste van sy werke op die internet beskikbaar stel. Jacobs, die publikasiehoof van Lux Verbi in 2003, het oor die stand van sake in Suid-Afrika se Christelike boekebedryf terugvoer gegee. Jacobs (2003) sê:

'n Trendsetter wat niemand natuurlik kon sien kom nie, was die dramatiese gebeure van 11 September 2001. Die afgelope jaar oorheers boeke oor lyding en God se rol daarin, en die sogenaamde teodisee-vraag na die wil van God, die publikasielyste. Ook in Suid-Afrika, al is ons nie so direk deur die gebeure in die VSA geraak nie, het boeke soos Adrio König se God, waarom lyk die wêreld só? groot belangstelling gaande gemaak. (bl. 40)

Hierdie boek is baie aktueel soos blyk uit die resensies en kommentaar in die koerante. Barry van der Merwe (2002:9) skryf: 'König se boek gee nuwe perspektief op 'n ou vraagstuk'. Die boek is nie net aktueel nie, maar ook kontroversieel en het talle openbare debatte ontlok.

In God, waarom lyk die wêreld so? (2002) behandel König Calvyn se voorsienigheidsleer in fyn besonderhede. König het ernstige kritiek teen Calvyn se voorsienigheidsleer. Calvyn se voorsienigheidsleer is net soos König s'n kontroversieel en hy is hieroor ook al deur talle teoloë aangeval. Calvyn word na 450 jaar weer opnuut hieroor deur König aangeval. Die vraag is egter of König Calvyn reg verstaan het en of König werklik nuwe vrae oor Calvyn se voorsienigheidsleer na vore bring.

\section{Debatte oor die voorsienigheidsleer waarin Calvyn betrokke was}

\section{Calvyn se debat met Pighius}

In 1542 skryf 'n Rooms-Katoliek van Kampen, Albertus Pighius, 'n geskrif teen Calvyn se leer oor die uitverkiesing. Hy beskou Calvyn se siening van die uitverkiesing en die voorsienigheid as 
laster teen die goedheid van God. ${ }^{1}$ Pighius begin sy boek, Die vrye wil van die mens, op dieselfde wyse as Calvyn se Institusie, met die gedagte dat kennis van God en kennis van die mens van mekaar afhanklik is. Calvyn reageer teen Pighius in 1543 met die boek, Gebondenheid en bevryding van die wil. ${ }^{2}$ In hierdie boek het Calvyn net op die eerste ses artikels van Pighius se werk gereageer. Calvyn het belowe dat hy die volgende jaar op Pighius se verstaan van die uitverkiesing sal reageer, maar kort daarna het die nuus van Pighius se dood Calvyn bereik en hy het besluit om nie verder op Pighius te reageer nie, 'sodat hy nie 'n dooie hond beledig nie' (Calvin 1961:10). Hierdie opmerking van Calvyn moet binne die laatmiddeleeuse debatvoering verstaan word (Calvin 2010:18). ${ }^{3}$

Calvyn het egter nege jaar later sy boek, Ewige uitverkiesing (1552), in Genève gepubliseer wat wel 'n reaksie op Pighius was. Hoewel Calvyn se reaksie hoofsaaklik 'n antwoord op Pighius se uitverkiesingsleer was, het dit beslis met Calvyn se voorsienigheidsleer verband gehou. Helm (1994:392) dui byvoorbeeld aan dat Pighius Calvyn se voorsienigheidsleer aanval, terwyl hy eintlik besig is om van uitverkiesing te praat. Nêrens spreek Calvyn Pighius pertinent aan oor die omruiling van die uitverkiesing en die voorsienigheid nie. Helm (ibid:393) toon dus aan dat Calvyn die uitverkiesing en die voorsienigheid as twee aspekte van dieselfde munt beskou. $^{4}$

\section{Calvyn se debat met Bolsec}

Die rede waarom Calvyn later vir Pighius geantwoord het, was as gevolg van hernude aanvalle op Calvyn se voorsienigheidsleer. Hierdie nuwe aanvalle het van Hieronymus Bolsec gekom. Bolsec was 'n oud-Karmelitiese monnik en doktor wat uit Frankryk gevlug en in Genève geskuil het. Bolsec het in Oktober 1551 Calvyn in die openbaar daarvan beskuldig dat Calvyn met sy leer oor die dubbele predestinasie God die outeur van die kwaad maak. Bolsec het Calvyn en Zwingli se leerstellings oor die uitverkiesing en die voorsienigheid veroordeel en gesê dit is in stryd met die Skrif (Kingdon \& Bergier 1962:1:99). Volgens Venema (1986:438) was Bolsec se eie siening ten opsigte van die uitverkiesing en die voorsienigheid in ooreenstemming met dié van die Rooms-Katolieke Kerk. Hulle leer dat daar samewerking tussen God en die mens is om die saligheid te verkry.

Bolsec was egter op die verkeerde tyd in die verkeerde dorp, omdat dit 'n tyd was met min verdraagsaamheid teenoor ketters. Ketters is veroordeel, toegesluit, verban en selfs

1.Pighius (1542) protesteer teen Calvyn se uitverkiesingsleer in De libero hominis arbitrio. (Die teks is beskikbaar in Vacant, Mangenot \& Amann 1935:12[2]:2100)

2.'Defensio sanae et orthodoxae doctrinae de servitute et liberatio humani arbitrii adversus calumnias Alberti Pighii Compensis' (Calvin 1863-1900; 6:225-404). Hierdie bron word verder as $\mathrm{CO}$ aangedui.

3. Hierdie gedeelte word gewoonlik aangehaal om te wys dat Calvyn ongeskik was. Aangesien die opmerking van Calvyn moontlik ongeskik voorkom, moet die manier van debatvoering van daardie tyd in ag geneem word: 'Calvin simply used the kind of coin then current, and the terms employed by his opponents were even less of coin then current, and the terms employed by his opponents were even less
restrained than his' (Calvin 1961:10). John Knox was ook uitgesproke toe hy na Pighius verwys het as 'that pestilent and perverse Papist' (Jedin 1927:17).

4.Vir ' $n$ verdere uitbreiding op Calvyn se reaksie op Pighius, vergelyk Schulze (1971). tereggestel deur die heerser aan bewind (Calvin 2010:18). Bolsec is daarom onmiddellik oor sy aantygings in die tronk gegooi. Hy is voor die Geneefse Raad verhoor, op grond van 17 onderskeie vrae skuldig bevind en uit Genève verban, aangesien hy geleer het dat die mens se saligheid van jou wil afhang - 'n leerstelling wat God se vrye genade ontken (CO 14:253).

Gedurende die verhoor het Bolsec hom op die leer van Melanchthon, Brenz en Bullinger beroep (Bangs 1961:158). Die raad van Genève het besluit om per brief te verneem na die predikante van Zürich se houding oor die saak. Dieselfde brief is ook in November 1551 na Basel en Bern gestuur. Die brief was 'n opsomming van die verloop van die debat asook 'n versoek aan die predikante om op die saak te reageer voordat die raad van Genève 'n oordeel sou vel (CO 8:207).

\section{Calvyn se debat met Bullinger}

Bullinger het in November 1551 op die brief van die Geneefse Raad in 'n private brief aan Calvyn gereageer (CO 14:207-209). Bullinger sê dat God 'n vriend van mense is en alle mense wil red, maar dat redding alleenlik uit genade en nie uit die werke van die mens kom nie; hy staan dus teenoor die leer van die Rooms-Katolieke Kerk en ook teen Bolsec. Bullinger het ook gesê dat diegene wat nie gered word nie, nie verdoem is omdat dit God se wil is nie, maar omdat hulle die genade van God verwerp (CO 14:208).

Bullinger het hom egter wel sterk teen die leer van Calvyn se dubbele predestinasie uitgespreek en gesê, ' $[g]$ lo my baie neem aanstoot teen jou leer van uitverkiesing in jou Institusie' (CO 14:215). ${ }^{5}$ Bullinger, nes Bolsec, het Calvyn ook daarvan beskuldig dat hy God as die outeur van die kwaad sien (CO 14:289-290).

Calvyn het eers in Januarie 1552, nadat Bolsec uit Genève verban is, op Bullinger se brief gereageer en Bullinger aangeraai om die gesprek privaat te hou ter wille van die eenheid van die kerk (CO 14:251). In Calvyn se reaksie op Bullinger se brief beleef ' $n$ mens nie dieselfde veglus as in sy reaksie teen byvoorbeeld Pighius, Bolsec of Castellio nie. In hierdie brief is daar eerder ' $n$ mismoedigheid by Calvyn te bespeur - die mismoedigheid van 'n dosent wat vir die honderdste maal iets verduidelik, maar die studente verstaan dit nog steeds nie. ${ }^{6}$

Calvyn het in sy antwoord aan Bullinger gesê dat hy God nie die outeur van die kwaad wil maak nie en dat dit 'n onregverdige beskuldiging was. Hy wil net die leer oor God

5.'Nam mihi crede plures offendi tuis Institutionibus de Praedestinatione editis, ac illud colligere quod collegit ex Zwinglii libro de providentia Hieronymus. Mea quidem sententia paucis sublimen hanc causam attigerunt apostoli, nec nisi coacti, eamque sententia paucis sublimen hanc causam attigerunt apostoli, nec nisi coacti, eamque sic moderati sunt ne quid inde offenderentur pii, sed omnes intelligerent Deum bene velle omnibus hominibus, ac in Christo offere salutem, quam ipsi, non sua virtute se non ullo sui respectu electi sint, reprobi vero sua culpa, non Dei malignitate, perire.'

6.Calvyn se teleurstelling blyk veral uit sy brief aan Farel op 08 Desember 1551 (CO 14:218). 
se genade teen Bolsec se leer, naamlik dat ons verlossing van ons eie wil afhang, verdedig (CO 14:252). Die debat tussen Calvyn en Bullinger het vir 10 jaar aangehou en volgens Bangs (1961:157) het hulle nie werklik tot 'n ooreenstemming gekom nie, hoewel Bullinger in 1562 wel die leer oor die uitverkiesing in die tweede Helvetiese belydenis ingesluit het. Hy het egter niks genoem oor die leer van die verwerping nie. ${ }^{7}$

\section{Calvyn se debat met Castellio}

Die Fransman Sebastian Castellio (1515-1563) was nog iemand wat in 'n debat met Calvyn oor die voorsienigheid van God was. Calvyn en Castellio het in Straatsburg ontmoet. Gedurende 1543-1544 was Castellio as 'n rektor in Genève aangestel en Calvyn was aanvanklik baie beïndruk met Castellio se vermoë om die grondtale te hanteer. Gedurende sy predikantstudie het Castellio egter afvallig begin raak en byvoorbeeld gesê dat die boek Hooglied uit die Kanon gehaal moet word. Hy het in 1544 by die kollege in Genève bedank en in 1553 is hy as professor in Grieks by die Universiteit van Basel aangestel. ${ }^{8}$

Na die teregstelling van Servet in 1553 het Castellio 'n persoonlike veldtog teen Genève begin. Hy het verskeie boeke teen Genève geskryf, spesifiek teen Calvyn se leer oor die uitverkiesing en die voorsienigheid. Anders as die private debat tussen Bullinger en Calvyn was Calvyn se debat met Castellio 'n openbare debat. Volgens Goad (Calvin 2010:16) het Castellio briewe onder die reformatoriese gemeenskap versprei wat teen die werke van Calvyn gerig was.

In September 1557, gedurende 'n besoek aan Basel, het Beza 'n manuskrip ontvang met 14 artikels oor die leer van die voorsienigheid en die uitverkiesing (Guggisberg 2003:139). Die dokument was in die vorm van 'n ope brief aan Calvyn geskryf. Calvyn het die dokument in November ontvang, maar aanvanklik getwyfel of hy daarop moes reageer (Calvin 2010:16). Calvyn was moontlik al moeg vir hierdie debat en het dalk gevoel dat die debat net meer skade as goed sou doen.

In Januarie 1558 het Calvyn egter tog gereageer toe hy Die verborge voorsienigheid van God (Calvin 1863-1900, 32:273-381) gepubliseer het. Die boek is in 14 artikels met kritiek op Calvyn verdeel en daarna volg Calvyn se reaksie op elke artikel. Vir die doeleindes van hierdie studie word slegs na artikels vyf en ses gekyk, omdat König ook dieselfde kritiek teen Calvyn se voorsienigheidsleer het. Hierdie artikels bevat ook drie verwysings na ander tekste wat Calvyn se verstaan van God se voorsienigheid goed saamvat. ${ }^{9}$

7.'De praedestinatione Dei, et electione sanctorum; (Bullinger 1866:x).

8.Vir besonderhede oor Castellio se lewe, vergelyk Guggisberg (2003).

9.Hierdie drie tekste is Calvyn (1863 [1559]) se Institusie (1.17.5), asook De aeterna Dei praedestinatione (Calvin 1961) en Calvyn se kommentaar op Handelinge 2 (Calvin 2005)

\section{Die kritiek van Castellio teen Calvyn in artikel 5 van Die verborge voorsienigheid van God}

In Die verborge voorsienigheid van God (Calvin 1863-1900) ${ }^{10}$ se vyfde artikel sê Calvyn volgens Castellio 'dat geen egbreek, diefstal of moord gepleeg word, sonder dat die wil van God betrokke is nie. Inst. Hfst. 14. par. 44' (Calvin 1840:59.) ${ }^{11}$ Die kritiek van Castellio (CO 9:278) op hierdie artikel kan opgesom word in die woorde 'God wil die sonde'. ${ }^{12}$ In sy kritiek gebruik Castellio vier keer die uitdrukking 'God wil die sonde'. Volgens Castellio sê Calvyn dat God die sonde wil, wat impliseer dat God self gestraf moet word. In hierdie kritiek sinspeel Castellio daarop dat Calvyn God in sy voorsienigheidsleer as die duiwel voorstel, want as God die sonde wil, sal die duiwel nie die sonde wil doen nie, omdat die duiwel in alles die teenoorgestelde van God is. Hierdie kritiek teen Calvyn is dieselfde as König se kritiek teen Calvyn. König vra: 'Hoe verskil Calvyn se God dan van die duiwel? Met 'n God soos Calvyn se God het 'n mens nie 'n duiwel nodig nie!' (König 2002:151).

\section{Calvyn se reaksie teen Castellio ten opsigte van artikel vyf}

In Calvyn (CO 9:301) se reaksie teen Castellio se kritiek begin hy dadelik met die voorsienigheid van God. Calvyn dui aan dat Castellio deur die voorsienigheid van God 'n gedeelte van die vyfde artikel neergeskryf het. Selfs net die kies van 'n teks of woorde is die voorsienigheid van God. Die beklemtoning van God se soewereiniteit is die fokuspunt van die Calvinisme en in die verdediging van Castellio se kritiek teen Calvyn, begin hy met die soewereiniteit van God. God beskik alle dinge, selfs die teks wat Castellio daar gekies het.

Calvyn roep die lesers verder op om die gedeelte in sy Institusie te gaan lees, want volgens Calvyn het Castellio na 'n gedeelte gegryp en die res van die skryfstuk uitmekaar geskeur. $^{13}$ Van Wyk (2002:541) het ook soortgelyke kritiek teen König se hantering van Calvyn en vra 'of dit wetenskaplik verantwoordbaar is om 'n outeur soos Calvyn se voorsienigheidsleer net aan die hand van sy Institusie weer te gee en te kritiseer'. Calvyn se voorsienigheidsleer behoort ook binne sy Godsleer, Christologie en Pneumatologie behandel te word, sodat die volle gedagte van Calvyn se voorsienigheidsleer in ag geneem word.

Castellio verwys in artikel vyf na Calvyn se Institusie, hoofstuk 14, paragraaf 44. Omdat Castellio hierdie kritiek teen Calvyn in 1557 geskryf het, kan dit nie na Calvyn se Institusie van 1559 verwys nie. Castellio kon ook nie na enige uitgawe vóór

10.Daar is tans drie Engelse vertalings waarvan die outeur bewus is. In 1840 het James Lillie Calvin on secret providence gepubliseer. Henry Cole het in 1856 drie van Calvyn se tekste wat noú aan mekaar verbonde is, vertaal, naamlik Concerning the eternal predestination of God geskryf teen Albertus Pighius, A brief reply teen Castellio gemik en A defence of the Secret Providence of God. Hy het al drie hierdie geskrifte saam in Calvin's calvinism gepubliseer. Die laaste uitgawe is 'n vertaling deur Keith Goad, The Secret Providence of God (2010).

11.'Nullum adulterium, furtum, homicidium committitur, quin Dei voluntas intercedat. Instit. cap. 13, distin. 44.' (CO 9:274.).

12.'Deus vult peccatum'

13. Mutilum dui hier op die amputering van 'n ledemaat. 
1550 verwys het nie, omdat die hoofstukke eers in 1550 in paragrawe verdeel is (De Greef 2008:188). Dit is dus die 1550teks waarna Castellio hier verwys. Calvyn (CO 1:893) begin in paragraaf 44 van hoofstuk 14 van die 1550-uitgawe met 'n argument wat sy teenstanders gewoonlik teen hom gebruik: 'Die bose en onwaardige dinge wat gebeur, reflekteer op die voorsienigheid van God. Alles gebeur in die orde van Goddelike voorsienigheid.' (CO 1:893.) ${ }^{14}$ Volgens die eerste ses sinne lyk dit asof Calvyn wel skuldig is, maar Castellio het duidelik nie verder as hierdie ses sinne gelees nie. Hy haal een sin uit, of soos Calvyn sê, sny een sin uit hierdie ses sinne en maak asof dit Calvyn se siening van die saak is.

Dit is heel moontlik die rede waarom Calvyn in die 1559-uitgawe van sy Institusie 'n klein verandering ingebring het net voor die gedeelte waarna Castellio verwys. Calvyn voeg aan die einde van paragraaf vier en die begin van paragraaf vyf van boek 1, 12 die volgende gedeelte in:

Daarom het ek tevore gewaarsku dat die voorsienigheid van God nie altyd oop en bloot op ons pad kom nie, maar op die een of ander wyse klee God dit in namate Hy sy middels daarvoor aanwend. Dieselfde mense trek verkeerdelik en ondeurdag die gebeure van die verlede deur na die blote voorsienigheid van God. Omdat alles wat gebeur, van sy voorsienigheid afhanklik is, sê hulle ... (Calvin [1559] 1986, Inst. 1.17.4-5) ${ }^{15}$

Deur die invoeging van sê hulle, probeer Calvyn aantoon dat dit nie hy is wat dit sê nie, maar sy teenstanders wat dit van hóm sê. Castellio haal dus Calvyn buite konteks aan en versprei hierdie valse aanhalings onder die publiek. Daarom gebruik Calvyn harde woorde teenoor Castellio: 'jy het gegryp na daardie verminkte teks en verdien jy nie dat almal in jou gesig spoeg nie?' (Calvin 1840:60). ${ }^{16}$

\section{Calvyn se verklaring van: 'God gebruik die sonde, maar wil dit nie' uit sy Institusie (Calvin [1559] 1986, Inst. 1.17.5)}

In hoofstuk 17, paragraaf drie, vier en vyf van sy Institusie mik Calvyn (CO 2, 156-158) teen dié wat dink dat God die sonde wil - juis dit waarvan Castellio vir Calvyn beskuldig. Calvyn stel God se wil en dit wat God ons in sy Woord onderrig, gelyk aan mekaar. 'Net iemand wat in verband met sy wil onderwys is, gehoorsaam God, ... Maar waaruit kan ons in sy wil geleer word anders as net die Woord'. (Calvin [1559] 1986, Inst. 1.17.5.) ${ }^{17}$ Tog gebeur daar dinge teen God se Woord en dus ook teen sy wil. Calvyn sê die bose mense verklaar dat die mens nie nodig het om te bid nie, omdat God alles reeds bepaal het. Hulle sê ook dat 'n sluipmoordenaar wat 'n eerbare burger vermoor het, net die

14. In iis quae iam contigerunt pessime et indignissime Dei providentiam reputant. Omnia quae fiunt in ordinem respiciunt divinae providentiae.

15.'Ideo ante admonui, providentiam Dei non semper nudam occurrere, sed prout adhibitis mediis eam Deus quodammodo vestit. lidem praeteriti temporis eventus perperam et inconsiderate ad nudam Dei providentiam trahunt. Nam quia ex ea van Simpson (Calvin [1559] 1986) word gebruik vir die tekste uit Calvyn se Institusie.

16.'Tu mutilum istud dictum arrispiens, nonne dingus es in cuius faciem omnes conspuant?' (CO 9:301)

17.'Paret ille Deo, qui de eius voluntate edoctus ... Unde autem edocemur, nisi ex eius verbo?' (CO 2:158). raad van God uitgevoer het (Calvin [1559] 1986, Inst. 1.17.3). Calvyn se reaksie hierop is dat God aan die mens die vermoë gegee het om te beraadslaag en teen enige gevare behoedsaam te wees en verder dat mense wat die bose dinge doen, nie die wil van God dien nie, ${ }^{18}$ omdat ons nie kwaad kan doen om aan God gehoorsaam te wees nie. 'As ons iets in stryd met sy gebod bedryf, is dit nie gehoorsaamheid nie, maar hardkoppige oortreding.' (Calvin [1559] 1986, Inst. 1.17.5) ${ }^{19}$ Calvyn stel die mens se selfontwerpte plan teenoor God se plan wat aan ons onderrig word. Indien ons ons eie ontwerpte plan volg, is dit nie gehoorsaamheid nie, maar ongehoorsaamheid teenoor die wil van God asook 'n aktiewe wegdraai vanaf die wil van God. Daarom kan ons volgens Calvyn nie kwaad doen om God se wil te gehoorsaam nie, 'ons storm eerder in die kwaad in sonder om aan sy wil te dink' (Calvin [1559] 1986, Inst. 1.17.5).

Deur aan te toon dat die mens vir die kwaad verantwoordelik is, probeer Calvyn nie die krag van die Skepper verminder of die soewereiniteit van God aantas nie, maar hy toon aan dat God die mens nie soos marionette geskep het nie. God het aan die mens rede en wilskrag gegee sodat hy keuses kan maak (Coetzee 2010:154). Die fokuspunt van die Calvinisme is juis die vashou aan God se soewereiniteit, ${ }^{20}$ al is die mens nie marionette nie en al kan die mens in kwaad instorm sonder om aan God se wil te dink. Dit verminder egter nie God se soewereiniteit nie.

Calvyn verduidelik hierdie aspek van God se soewereiniteit deur na God as die regverdige Regter te verwys. ${ }^{21}$ As gevolg van Calvyn se juridiese agtergrond beskryf hy God se soewereiniteit in regsterme.22 Calvyn ([1559] 1986, Inst. 1.18.1) verwys byvoorbeeld na Dawid wat erken dat God 'n regverdige Regter is en bely dat die vloek van Simeï uit die bevel van God voortkom. Dawid sê: 'Die Here het hom beveel om my te vloek' (2 Sam 16:10). Deur dus kwaad te doen, kan die mens God se regverdige verordenings dien (Calvin [1559] 1986, Inst. 1.17.5) ${ }^{23}$ net soos Simeï se bose dade ook God se regverdige verordenings gedien het.

Calvyn verwys nie net na die verordenings (ordino) nie, maar spesifiek ook na die regverdige verordenings (iustae ordinationi), omdat Calvyn teen die gedagte van willekeur waak, aangesien willekeur soos die noodlot net 'n planmatige bloudruk kan voorstel. Dit is hiervan wat König vir Calvyn beskuldig. Volgens König (2002:153) leer Calvyn dat die lewe ' $n$ toneelstuk is wat opgevoer word en waarin die regisseur nie nuwe beslissings kan neem nie.

18.'Sed enim eos Dei voluntati servire nego' (CO 2:158).

19.'Si quid adversus praeceptum designamus, non obedientia est, sed contumacia et transgressio' (CO 2:158).

20.Indien Jonathan Edwards as Calvinisties beskou word, is dit óf omdat hy aan die Woord van God, óf die soewereiniteit van God vashou (Marsden 2003:437).

21.Lee (2008:2) verwys na Calvyn as die prokureur-teoloog. Nadat Calvyn sy M.A.-graad ontvang het, het hy in die Regte gaan studeer. Hy het eerste onder Pierre Taisan d'Etoile en toe onder die Italiaanse juris Andrea Alciati studeer en in 1531 het Calvyn sy Doktorsgraad in die Regte verwerf.

22.Calvyn gebruik regsterme soos iustae, ordinationi, exsequenda, constituit en iudicia.

23.'Atque hac ratione, male agendo, iustae eius ordinationi servimus' (CO 2:158). 
Volgens Britz (2008:11) verstaan Calvyn God se regering nie op 'n planmatige, deïstiese manier nie. Britz (ibid:7) dui aan dat Calvyn verstaan dat die verhouding tussen die voorsienigheid van God en die geskiedenis as realiteit (dit sluit die kwaad in), vasgevang moet word in die leer van die Skrif as dinamiese kategorieë en nie as statiese kategorieë nie. In hierdie beginsel breek Calvyn ook met die passiewe goddelike determinisme (Emerson 1956:142). Deur na God as die regverdige Regter of na God se regverdige verordenings te verwys, beklemtoon Calvyn die persoonlike element van God se voorsienigheid. Die kwaad dien nie bloot God se verordenings nie, maar dit dien God se regverdige verordenings. Calvyn verwys na God se soewereiniteit as die regverdige Regter wat 'n saak op 'n regverdige wyse aanhoor. Soos 'n vader wat na die saak van sy kind luister, so luister God as Vader ook regverdig na sy kinders se regsaak. God se verordenings is dus nie 'n willekeurige noodlot nie, maar persoonlike regverdige verordenings. ${ }^{24}$

Calvyn probeer nie om die kwaad te verklaar nie, maar hy toon aan hoe die kwaad wat ons doen die regverdige verordenings van God dien, 'omdat Hy na die onmeetlike grootheid van sy wysheid weet hoe om slegte instrumente goed en na behore te gebruik' (Calvin [1559] 1986, Inst. 1.17.5). ${ }^{25}$ God kan in sy alwetendheid en almagtigheid slegte instrumente goed gebruik. Daarom verwys Calvyn na die 'onmeetlike grootheid van sy wysheid'. Dit is ook die rede waarom Calvyn van die verborge voorsienigheid van God praat. Die mens kan nie verstaan hoe God slegte instrumente goed kan gebruik nie, maar God weet deur die onmeetlike grootheid van sy wysheid, of sy verborge voorsienigheid, hoedat die kwaad wat ons doen, sy regverdige verordening dien.

In Calvyn se voorsienigheidsleer word die woord voorsienigheid op talle plekke langs die woord verborge gebruik. Telkens word die Latynse byvoeglike naamwoord occulta (verborge) aan God se voorsienigheidhandelings verbind. Daarom noem Calvyn sy geskrif aan Castellio Die verborge voorsienigheid van God. Calvyn handhaaf deurgaans die siening van ' $n$ bepaalde verborgenheid in God se voorsienigheid. Verskeie teoloë het kritiek teen hierdie beskouing van Calvyn, byvoorbeeld Berkhof (1973:229) wat sê dit is 'n 'vlug in die onbegryplikheid van God'. ${ }^{26}$ König kritiseer Calvyn ook op die punt van God se verborge voorsienigheid. Volgens König is dit omdat Calvyn se voorsienigheidsleer so vreemd is dat dit hom dwing om met alle mag aan die verborgenheid van God se voorsienigheid vas te hou. Volgens König gryp Calvyn na God se verborge voorsienigheid sodra hy iets nie kan verklaar nie. Hierop vra König (2002:70-71): 'as God se wil so verborge is en nie verstaan kan word nie, hoekom het Hy vir ons die Bybel gegee?'

24.Volgens Coetzee (2010:151) is Calvyn se klem op God as die Vader' $n$ aanduiding van God se persoonlike versorging van sy kinders.

25.'... quia pro immensa suae sapientae magnistudine, ad bene agendum malis instrumentis uti bene probeque novit' (CO 2:158). Beveridge (Calvin [1559] 1863:138) vertaal bene eerder as 'n bywoord van novit as van agendum: '... since in his boundless wisdom he well knows how to use bad instruments for good purposes'.

26.Ook Dowey (1947:7) het kritiek teen die vlug na die 'mysterious will'.
Dit is egter nie net Calvyn wat die voorsienigheid en die verborgenheid langs mekaar plaas nie, maar ook sommige van die kerkvaders. Sommige kerkvaders verklaar die probleem van die kwaad ook as die verborgenheid van die voorsienigheid. Origenes (1836:7) noem dat alle dinge as gevolg van die voorsienigheid van God gebeur of bestaan, maar dat sekere gebeure so misterieus ontvou dat die plan aangaande die gebeure totaal verborge is. Hierdie misterieuse gebeure lyk soms asof dit nie deel is van God se voorsienigheid nie, maar dit ís wel deel van God se verborge voorsienigheid. Volgens Origenes is God se voorsienigheid nie so duidelik in die fisiese dinge as in die geestelike dinge nie. ${ }^{27}$ Lactantius (1973:39) verwys na die verborgenheid van die voorsienigheid wanneer hy van die onuitspreeklike krag van die voorsienigheid praat $^{28}$ en ook dat God se voorsienigheid nie in woorde uitgedruk word nie.$^{29}$ Dit is dus nie net Calvyn wat God se voorsienigheid 'n verborgenheid noem nie, maar ook sommige van die kerkvaders.

Volgens Calvyn moet die mens met groot beheerstheid oor die verborge geheimenisse van die Skrif redeneer. 'n Mens moet ook versigtigheid aan die dag lê sodat jou woorde en gedagtes nie die grense van die Woord van God oorskry nie. 'Want hoe sou die mens se verstand na sy geringe maat die onmeetlike Wese van God kan peil ...' (Calvin [1559] 1986, Inst. 1.13.21). ${ }^{30}$ Dit is in hierdie konteks dat die verborgenheid van God se raad verstaan moet word. Die Woord van God is ook duidelik dat daar sekere dinge is wat die mens nog nie weet nie, omdat dit nog nie aan die mens geopenbaar is nie. Vergelyk Jesaja 55:8: 'Want my gedagtes is nie julle gedagtes nie, en julle weë is nie my weë nie, spreek die HERE.'

Calvyn ([1559] 1986, Inst. 1.17.2) toon vanuit die volheid van die Skrif aan dat God se oordele verborge is; hy verwys byvoorbeeld na Deuteronomium 30:11-14, Psalm 36:7 en Romeine 11:33. Hy sê verder:

... dit is wel waar dat God se geheimenisse, wat die maat van ons verstand ver te bowe gaan, in die Woord van God saamgevat word. God verlig egter die verstand van sy kinders om hierdie geheimenisse te begryp wat God waardig geag het om aan ons in sy Woord te openbaar. Hierdie geheimenisse is dus nie meer vir ons 'n afgrond nie, maar eerder 'n weg waarop ons veilig kan wandel ... (Calvin [1559] 1986, Inst. 1.17.2)

In sy beredenering noem Calvyn ([1559] 1986, Inst. 1.17.1) dat sommige oorsake en gebeurtenisse duidelik verborge is, byvoorbeeld in die gebeurtenis van die man wat blind gebore is. Jesus sê hieroor: 'Hy het nie gesondig nie en sy ouers ook nie, maar dit het geskied sodat die heerlikheid van God

27.'Nam cum certum sit omnia quae hoc in mundo sunt, vel geruntur, Dei providentia dispensari, quaedam quidem satis evidenter apparent, quod providentiae gubernatione digesta sint; alia vero tam occulte tamque incomprehensibiliter explicantur, ut penitus in his lateat divinae ratio providentiae ita ut interdum a nonnullis: nec credantur quaedam ad providentiam pertinere, quoniam ratio ab eis latet per quam ineffabili: quadam arte opera divinae providentiae dispensantur, quae tamen ratio non aequaliter omnibus occultata est.'

28.'Ergo ineffabilis divinae providentiae virtus fecit duos simillimos orbes'.

29.... cujus divinam providentiam perfectissimamque virtutem, nec sensu comprohendere, nec verbo enarrare possibele est'.

30.'Quomodo enim immensam Dei essentiam ad suum modulum mens humana definiat ...' (CO 2:107). 
in hom geopenbaar kan word' (Joh 9:3). Verder sê Calvyn ([1559] 1986, Inst. 1.17.1) dat die mens se gevoel wel daarteen indruis dat God mense wat dit nie verdien nie so verdruk. Tog getuig Christus dat die Vader deur die genesing van die blinde man verheerlik word:

Maar ons moet ingetoënheid aan die dag lê om nie by God aan te dring om 'n rede vir sy optrede te gee nie, maar om sy verborge oordele so te eerbiedig dat sy wil vir ons die mees gegronde oorsaak van alle dinge is. (Calvin [1559] 1986, Inst. 1.17.1.)

Die mens moet volgens Calvyn ([1559] 1986, Inst. 1.17.1) nie die dade van God tot rekenskap roep en 'n oordeel vel oor God se verborge raad wat vir die mens onbekend is nie. Ons moet ook nie met die verborge oordele van God spot nie, maar eerder daarna opsien.

Volgens Van der Molen (1978:31) kan Calvyn se voorsienigheidsleer nie in 'n metode vasgevang word nie, omdat God 'n persoonlike God is wat vir sy kinders soos 'n Vader sorg. Hierdie versorging van God is volgens Van der Molen (ibid:32) dit wat Calvyn God se verborge voorsienigheid noem, want geen mens weet hoe die Vader vir sy kinders gaan sorg nie; ons kan slegs weet dat die Vader wel vir hulle sorg. Verder sê Van der Molen (ibid:33) dat Calvyn se versigtigheid vir menslike kennis die sleutel is tot die verstaan van God se voorsienigheid, omdat die mens se gedagtes nie God se gedagtes is nie en God se gedagtes nie in 'n metode vasgevang kan word nie.

Binne die konteks van die verborge voorsienigheid van God moet die volgende woorde van Calvyn ([1559] 1986, Inst. 1.17.5) verstaan word:

Sover dit my aangaan, gee ek nog meer toe, naamlik dat diewe, moordenaars en ander boosdoeners ook instrumente van God se voorsienigheid is waarvan die Here gebruik maak om sy beskikking ten uitvoer te bring. Maar ek ontken dat hulle bose dade daarom verskoon moet word. ${ }^{32}$

In God se verborge voorsienigheid gebruik God soms slegte instrumente om sy regverdige besluit uit te voer. Direk daarna stel Calvyn egter dat hierdie bose dade of slegte instrumente nie verskoon kan word nie. God kan nie die bose dade verskoon nie, omdat dit teen sy wet of wil is.

Op hierdie punt is daar baie kritiek teen Calvyn se voorsienigheidsleer. God wat die slegte instrumente gebruik om sy wil te dien, maar nie die dade van die slegte instrumente wil aanvaar nie. ${ }^{33}$ Hierdie problematiek is vir Calvyn 'n geloofsbelydenis. Net soos wat die belydenis van die Drie-eenheid of die belydenis van die twee nature van Christus vir ons sekere verborgenhede het, net so het die belydenis van God se voorsienigheid sekere verborgenhede.

31.Sed tenenda modestia est, ne ad causam reddenadam Deum trabamus: sed ita revereamur occulta eius iudicia, ut nobis eius voluntas iustissima sit rerum omnium causa' (CO 2:152).

32.'Ego plus concedo: fures et homicidas et alios maleficos, divinae esse providentiae instrumenta, quibus Dominus ipse ad exsequenda quae apud se constituit iudicia utitur. Atqui eorum malis ullam inde excusationem deberi nego' (CO 2:158).

33.Goad (Calvin 2010:26) noem dat Calvyn sê 'God wills what He does not will.'
Calvyn hou egter vas aan die geopenbaarde wil van God, naamlik dat God almagtig en soewerein is en dat sonde ook teen sy wil is. ${ }^{34}$

\section{Die kritiek van Castellio teen Calvyn in artikel 6 van Die verborge voorsienigheid van God}

Volgens Castellio (CO 9:274) sê Calvyn dat die Skrif nie net getuig dat misdade deur die wil van God bedryf word nie (soos hy dit in artikel 5 bespreek), maar dat misdade ook deur die gesag (autore) van God bedryf word. Castellio (CO 9:278) se kritiek teen Calvyn is dat hy God die outeur van die kwaad maak en as God die outeur van die kwaad is, moet Hy ook vir die sonde gestraf word, omdat die sondaar nie van die sonde losgemaak (animadvertendum) kan word nie.

\section{Calvyn se reaksie teen Castellio ten opsigte van artikel ses}

Calvyn (CO 9:301) begin sy reaksie op artikel ses van Castellio deur na Castellio se onwetenskaplikheid te verwys. Castellio toon byvoorbeeld nie aan waar hy die gedeelte gekry het waarna Calvyn verwys nie. Calvyn toon Castellio se vermetelheid aan deur te wys op sy verkeerde aanhalings van Calvyn en ook die foutiewe implisering dat Calvyn dinge sê wat hy nie gesê het nie. Volgens Calvyn (CO 9:301) waarsku hy altyd voordat hy van sonde praat, dat God en sonde ver uitmekaar gehou moet word. Met groot verbasing vra Calvyn 'of hy al ooit gesê het, dat oortredinge nie net gepleeg is deur die wil van God nie, maar ook deur die gesag van God'. ${ }^{35}$

So 'n uitspraak is volgens Calvyn (CO 9:301) lasterlik en hy wil nie sy naam daaraan verbind nie. Die onwetenskaplikheid en oneerlikheid van Castellio mislei die publiek ook; indien die mense egter Calvyn se werke met Castellio se uitvindings of uittreksels vergelyk, sal hulle sien dat Castellio se werk die vervloeking moet kry wat dit verdien.

Calvyn se moedeloosheid oor die onderwerp kom duidelik na vore in sy verwysing na ander tekste wat hy oor die onderwerp geskryf het: 'Want dit was nie gister die eerste keer, of die dag voor dit nie, maar baie jare voor dit dat ek al hierdie soort taal gebruik het ...' (Calvin 1840:61). Calvyn is deur talle mense oor sy leer van God se voorsienigheid aangeval, maar Castellio neem nie hierdie antwoorde van Calvyn in ag nie - net soos König dit ook nie doen nie.

\footnotetext{
34.Calvyn se noue verbinding en invloed op die gereformeerde belydenisskrifte moet ook in ag geneem word. Bierma (2010) het ' $n$ vergelykende studie gedoen tussen Calvyn se Geneefse Kategismus en die Heidelbergse Kategismus. Sy (Bierma 2010:8 bevinding is dat sommige van die bewoording in die Heidelbergse Kategismus nóu verbind is met die Geneefse Kategismus, byvoorbeeld die ooreenkomste in die Heidelbergse Kategismus vraag en antwoord 26 en die Geneefse Kategismus se ooreenstemmende 22. Daarin word gestel dat God ons Vader is as gevolg van Jesus Christus. In die Heidelbergse Kategismus se vraag en antwoord 26 en die Geneefse Kategismus 24 assosieer albei die voorsienigheid met God se raad. Calvyn noem ook in die Geneefse Kategismus (vraag en antwoord 27) die opsomming van die 'reën in Geneefse Kategismus (vraag en antwoord 27) die opsomming van die 'reen en droogte, vrugbare en onvrugbare aarde, gesondheid en krankheid' wat ook in die Heidelbergse Kategismus se ooreenstemmende vraag 27 voorkom (slegs in meer detail uitgewerk). Daar is nog talle ander voorbeelde ook waar Bierma (2010) die noue verband tussen die Geneefse Kategismus en die Heidelbergse
Kategismus aandui.

35. '... usquam dixerim maleficia non tantum eo volente, sed etiam autore perpetrari?' (CO 9:301).
} 
König (2002:65) sê, net soos Castellio, dat Calvyn God die outeur van die kwaad maak sonder dat König enige debatte van Calvyn oor die onderwerp van God se voorsienigheid in ag neem. Sake waarmee Castellio en König 'n probleem het, is reeds in die debatte wat Calvyn gevoer het, uitgewys. Dit is jammer dat nie Castellio of König hierdie debatte in ag geneem het nie, omdat Calvyn in die debatte die meeste, indien nie al Castellio en König se vrae beantwoord nie. Dit sou dalk meer sinvol gewees het indien Castellio of König op hierdie antwoorde van Calvyn gereageer het.

Sonder om die onderwerp 'God is nie die outeur van die sonde nie' in hierdie brief aan Castellio in diepte uit te werk, verwys Calvyn sy lesers na twee tekste, die boek oor die ewige uitverkiesing (Calvin 1961) en sy kommentaar op Handelinge 2 (Calvin 2005). Calvyn raai lesers aan om die hele gedeelte wat oor God se voorsienigheid handel in die boek oor die ewige uitverkiesing na te gaan, sodat hulle self kan sien dat al Castellio se aanvalle 'soos mis verdwyn' (CO 9:302).

\section{Calvyn se verklaring van 'God is nie die outeur van die sonde nie' uit Ewige uitverkiesing en Handelinge 2}

In Die verborge voorsienigheid van God haal Calvyn 'n groot gedeelte aan uit die Ewige uitverkiesing. ${ }^{36}$ In hierdie gedeelte van die Ewige uitverkiesing bespreek Calvyn waarom God nie die outeur van die kwaad is nie. Calvyn (CO 8:361) verwys na die gebeure van Job en al die slegte dinge wat met Job gebeur het, byvoorbeeld die diewe wat Job se vee steel en die Satan wat Job met verdere swaarkry versoek. Hoewel dit die rowers en die Satan was wat die dinge oor Job gebring het, wys Job op 'n ander outeur. ${ }^{37}$ Job bely nie 'n magtelose God wat net passief toekyk terwyl die rowers en die Satan die bose dade doen nie. Hy sê: 'Die Here het gegee en die Here het weggevat' ${ }^{38}$

Job getuig van die slegte dinge wat met hom gebeur het asof hy een van die ooggetuies was tydens die hemelse raad waar besluit is wat met Job gaan gebeur. ${ }^{39}$ Dit is waarskynlik die rede waarom Calvyn (2010) sy lesers in Die verborge voorsienigheid van God na sy kommentaar op Handelinge 2 verwys, want Handelinge 2:23 stel dat die slegte gebeure met Christus ook volgens die bepaalde raad en voorkennis ('definito consilio et praescientia') van God was. ${ }^{40}$

Volgens König (2002:173) is die kruisiging 'n voorbeeld van 'n nederlaag wat God ly, omdat die kruisiging volgens

36.Die aanhalingstekens in die vertaling van Lillie (Calvin 1840:61) is misleidend, omdat die eerste sin waarna Calvyn in die teks verwys nie ' $n$ aanhaling is nie. Dit gee slegs agtergrond tot die teks. Calvyn haal eers aan vanaf '... how shall God be exempted ....

37.'Atqui lob autorem alium praedicat' (CO 8:361)

38.'Dominus dedit, Dominus abstulit.' (CO 8:362.)

39.'Nam perinde ac si oculis spectasset, quae in coelesti consessu gesta esse historia narrat ...' (CO 8:362).

40.'Hom, wat deur die bepaalde raad en voorkennis van God ( $\dot{\omega} \iota \sigma \mu \varepsilon \dot{v} \eta \eta$

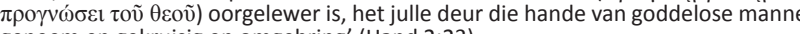
geneem en gekruisig en omgebring' (Hand 2:23).
König 'n mislukte poging was om Israel te probeer verlos. In Calvyn se kommentaar op Handelinge 2 toon hy aan dat die kruisiging van Jesus Christus volgens die bepaalde raad van God was, omdat Christus nie per toeval gely het nie, maar Christus se lyding so deur God bepaal is. ${ }^{41}$ König gaan in hierdie stelling direk teen die Skrif in en dit is teen sulke verkeerde en bose gedagtes waarteen Handelinge 2:23 getuig (Calvin 1667:16). ${ }^{42}$

God het deur sy instemming ${ }^{43}$ en gesag alles van Job weggeneem en Christus laat kruisig 'deur die hande van die plunderaars' (CO 8:362). ${ }^{44}$ Alles wat gebeur het, het gebeur 'soos wat God dit wou gehad het' (Calvin 1961:180). Volgens Calvyn leer ons hieruit dat die werk gesamentlik tussen God, die Satan en die rowers gedoen is. Hierdie afleiding is nie iets wat Calvyn uitgedink het nie, want dit is Job se eie woorde: 'Die Here het gegee en die Here het geneem' (Job 1:21). Calvyn neem dus sy vertrekpunt uit die Skrif, sonder om dit te betwyfel. ${ }^{45}$

Hierdie gedagte som Calvyn in die inleidende sin op, voor sy direkte aanhaling uit die Ewige uitverkiesing: 'As God, Satan en die rowers gesamentlik gewerk het in die verdrukking van Job ...' (Calvin 1840:61). Calvyn haal ook hierdie gedeelte uit Ewige uitverkiesing in Die verborge voorsienigheid van God direk aan. Calvyn toon dus aan dat God deel in die werk van Satan en die rowers. Hierop vra Calvyn (1840:61): 'Hoe sal God dan uitgesluit word van die skuld wat Satan en sy instrumente toekom?'46 Hierdie vraag word weereens uit Calvyn se regskennis beantwoord. Calvyn gee die voorbeeld van 'n bose man wat die oë van 'n kraai uithaal of 'n groot sprinkaanvoël doodmaak. Hierdie bose daad word veroordeel, maar die goeie deug van 'n regter word geprys wanneer hy 'n krimineel tot die dood veroordeel. Die regter word tog nie beskuldig vir die veroordeling van die krimineel nie. So moet 'n mens God ook as die regverdige Regter van die bose dade van die mens onderskei (Calvin 1961:180).

Daar word tog 'n duidelike onderskeid getref tussen die dade van 'n mens en die doel en uiteinde van die dade (CO 8:301). Calvyn onderskei tussen die plan of raad van God (vgl. Hand 2:23) en die plan of raad van mense

41. Quoniam ergo crux Christi primo adspectu nos turbare solet, ideo Petrus admonet nihil fortuito passum esse, vel quia illi ad se liberandum facultas defuerit, sed quia sic a Deo constitutum fuerat' (Calvin 1667:16).

42.'For this knowledge alone, that the death of Christ was ordained by the eterna counsel of God, did cut off all occasion of foolish and wicked cogitations ...' (Calvin 2005:96)

43.Calvyn gebruik spesifiek nuo (in die teks nutu) in plaas van voluntas. Beveridge (Calvin [1559] 1863, Inst. 3.8.11) vertaal byvoorbeeld nuo ook met die wil van God. Hier moet egter onderskei word tussen nuo en voluntas. Calvyn se gebruik van nuo dui eerder op die instemming of toestemming van 'n saak sodat God se wil (voluntas) bereik kan word. God wil (voluntas) dalk nie 'n saak nie, maar Hy laat dit wel toe (nuo) sodat God se doel bereik kan word.

44.'abstulisse per manus latronum ...'.

45.'The Scripture teacheth us far otherwise, which ascribeth unto God a special government in all things, and in man's actions. Notwithstanding, it is our duty to ponder and consider to what end it teacheth this; for we must beware of doting speculations, wherewith we see many carried away' (Calvin 2005:96).
spar

46.'... quomodo a culpa eximetur Deus, cuius Satan cum suis organis reus erit?' (CO 8:301). 
soos gestel in Psalm 2:2. 'Die konings van die aarde staan gereed en die vorste hou saam raad teen die Here en teen sy Gesalfde.' Net soos die mens raad of 'n vergadering hou en dan die besluite van die raad uitvoer tot die einde toe, so hou God ook raad en voer ook sy besluite tot die einde uit; die beplanning en die uitvoering van die raad moet egter van mekaar onderskei word.

Wanneer mense diefstal of moord pleeg, sondig hulle, omdat die dade van diefstal en moord uit 'n bose raad of plan ontwikkel het. God se raad is egter volkome reg en God wyk nooit daarvan af nie. Daarom word God in 'n hoër posisie as die diewe en die moordenaars geplaas, omdat God 'n breër visie as die mens het. God kan die boosheid dus gebruik om mense te tugtig en geduld te leer 'sonder dat God die outeur van die sonde is' (CO 9:302). ${ }^{47}$

Aangesien die oorsaak van sonde in die mens se slegte wil geleë is, is God glad nie skuldig in die uitvoering van sy regverdige oordele deur die hande van die slegte wil van die mens nie. ${ }^{48}$ God deel ook nie in die slegte wil van die mens nie, maar God bring die lig van sy heerlikheid uit die duisternis (CO 9:302). ${ }^{49}$ Die gedagte om God en die sonde te vermeng, juis dit waarvan Castellio en König Calvyn beskuldig, mak Calvyn so kwaad dat dit die toorn uit die diepste hel teen hom laat opborrel (Calvin 1840:62). Sommige mense trek die regter, wat nie by die sondige daad betrokke was nie, by die veroordeling in en hierdie gedagte is vir die menslike verstand absurd (CO 9:302). Hoeveel te meer nie om God die skuld vir die slegte omstandighede in die wêreld te gee nie? ${ }^{50}$

\section{Gevolgtrekking}

Calvyn se voorsienigheidsleer was baie kontroversieel. Dit word duidelik uit die debatte wat Calvyn met Pighius, Bolsec, Bullinger en Castellio gevoer het. Sy frustrasie was dat sy teenstanders hom oor dieselfde onderwerpe bly kritiseer het, sonder dat hulle die vorige debatte in ag geneem het. ${ }^{51}$ König het ook nie die debatte en die ingewikkeldheid rondom Calvyn se verstaan van God se voorsienigheid in ag geneem nie.

Calvyn het nie net debatte aangeknoop ter wille van aktualiteit nie. Hy het met wysheid sekere debatte privaat gevoer, byvoorbeeld met Bullinger, sodat die eenheid van die kerk daardeur bewaar kon word. Calvyn het ook nie die diepte van die debat prysgegee ter wille van aktualiteit nie. Hy wys nog steeds vir Pighius en Castellio op hulle onwetenskaplikheid. In hierdie verband het hy Pighius van

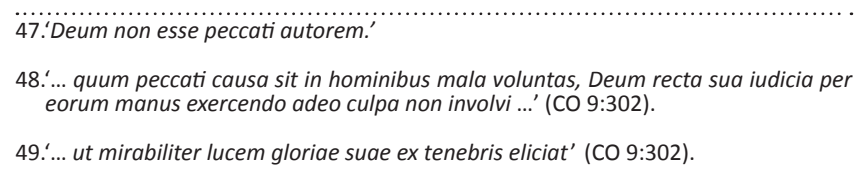

48.'... quum peccati causa sit in hominibus mala voluntas, Deum recta sua iudicia per eorum manus exercendo adeo culpa non involvi ...' (CO 9:302).

49.'... ut mirabiliter lucem gloriae suae ex tenebris eliciat' (CO 9:302).

50.In hierdie opsig is die naam van König se boek, God waarom lyk die wêreld so? Kan ons sê: 'God is in beheer'? misleidend. Dit mislei baie mense wat nie die boek lees nie, maar wel die titel lees, omdat dit God by die sonde van die mens intrek.

51.Om hierdie rede sê Calvyn (1840:63) vir Castellio: 'I have published a work twelve years since, which more than sufficiently vindicates me from your putid calumnies, and should have protected me from all annoyance, if in you and those like you, there were one drop of humanity.' plagiaat beskuldig, omdat Pighius groot dele van Calvyn se Institusie gebruik het sonder om een keer Calvyn se naam te noem (Schulze 1971:25). Dieselfde geld vir Castellio wat Calvyn buite konteks aanhaal (vgl. 'Calvyn se reaksie teen Castellio ten opsigte van artikel vyf'). Op dieselfde wyse gaan König ook onwetenskaplik te werk deur Calvyn buite konteks te lees. König (2002) verwys slegs na dele uit Calvyn se Institusie, maar neem nie die debatte waarin Calvyn betrokke was, in ag nie. Gevolglik het König dieselfde kritiek as Pighius, Bolsec, Bullinger en Castellio teen Calvyn, sonder dat König Calvyn se antwoorde in ag neem.

Calvyn het volgehou om die leer van God se voorsienigheid te verdedig, omdat die voorsienigheidsleer vir Calvyn ([1559] 1986, Inst. 1.17.8) die hart van die leer oor God se vertroosting is. Dit is 'n vertroosting wat König (2002:236) verwoes deur te verklaar dat God nie alle rampe kan keer of alle probleme kan oplos nie; nie omdat God nie wil nie, maar omdat God nie kan nie. Hierteenoor rig Calvyn ([1559] 1986, Inst. 1.17.8) 'n mens se oë op die voorbeeld van Josef en sy broers. Josef het nie in die verraad van sy broers bly vassteek nie, maar hy het sy gemoed tot die Here opgehef en sy broers vertroos met die woorde: 'Dit is nie julle wat my in Egipte verkoop het nie, maar ek is deur die wil van God voor julle uitgestuur om julle lewens te red' (Gen 45:8). 'Julle het wel die kwaad teen my bedink, maar die Here het dit ten goede verander' (Gen 50:20). Calvyn wys daarop dat ons getroos kan wees, omdat alle dinge in ons lewe - teenspoed en verdrukking deur God beskik word, met die doel om ons nader aan Hom te lei.

\section{Erkenning Mededingende belange}

Die outeur verklaar dat hy geen finansiële of persoonlike verbintenis het met enige party wat hom nadelig kon beïnvloed het in die skryf van hierdie artikel nie.

\section{Literatuurverwysings}

Bangs, C., 1961, 'Arminius and the Reformation', Church History 30(2), 155-170. http://dx.doi.org/10.2307/3161969

Berkhof, H., 1973, Christelijk geloof, Callenbach, Nijkerk.

Bierma, L.D., 2010, 'Calvin's influence on the Heidelberg Catechism: The doctrine of providence', paper presented at the International Calvin Congress, University of the Free State, Bloemfontein, 22-27 August.

Britz, R.M., 2008, 'Paupertas (Poverty) in John Calvin's Institutes', Acta Theologica, suppl. 10, 1-24.

Bullinger, H., 1866, Confessio Helvetica posterior, Apud Guilielmum Braumüller, Vindobonae.

Calvin, J., 1667, Joannis Calvini: Magni theologi, commentarri in Acta Apostolorum, ab ipso authore recogniti \& magna accessione locupletati, Schipper, Amstelodomi.

Calvin, J., 1840, Calvin on 'Secret providence', transl. J. Lillie, Carter, New York.

Calvin, J., 1856, Calvin's Calvinism, transl. H.P. Cole, Sovereign Grace Union, London.

Calvin, J., 1863-1900, 'Opera quae Supersunt Omnia', in G. Baum, E. Cunitz \& E. Reuss (eds.), Corpus Reformatorum, Schwetschke, Braunschweig.

Calvin, J., [1559] 1863, The Institutes of the Christian religion, Book 1-4, translated from Latin to English by H. Beveridge, Christian Classics Ethereal Library, Grand Rapids.

Calvin, J., 1961, Concerning the eternal predestination of God, transl. \& intro. J.K.S. Reid, Clarke, London.

Calvin, J., [1559] 1986, Institusie van die Christelike godsdiens, boek 1, vert. H.W. Simpson, Calvijn Jubeleum Boekefonds (CJBF), Potchefstroom. 
Calvin, J., 2005, Commentary upon the Acts of the Apostles, edited from the original English translation of Christopher Featherstone by Henry Beveridge, Baker Book House, Grand Rapids.

Calvin, J., 2010, The secret providence of God, transl. K. Goad, intro. P. Helm (ed.), Crossway books, Wheaton.

CO see Calvin, J., 1863-1900

Coetzee, C.F.C., 2010, 'The doctrine of providence in the "Institutes" of Calvin - Still relevant?', In die Skriflig/In Luce Verbi 44(3), 145-166.

De Greef, W., 2008, The writings of John Calvin, Westminster John Knox Press, Louisville.

Dowey, E.A., 1947, The knowledge of God in Calvin's theology, Columbia, New York.

Emerson, E.H., 1956, 'Calvin and covenant theology', American Society of Church History 25(2), 136-144. http://dx.doi.org/10.2307/3161198

Guggisberg, H.R., 2003, Sebastian Castellio 1515-1563: Humanist and defender of religious toleration in a confessional age, transl. B. Gordon (ed.), Ashgate, Aldershot.

Helm, P., 1994, 'Calvin (and Zwingli) on divine providence', Calvin Theological Journal 29, 388-405.

Jacobs, L., 2003, 'Huidige tendense in die Christelike boeke bedryf', Kruisgewys 3(1), 40.

Jedin, H., 1927, Des Johannes Cochlaesus streitschrift de libero arbitrio hominis, Nischkowsky, Breslau.

Kingdon, R.M. \& Bergier, J.F., 1962, Registres de la Compagnie des pasteurs de Genève au temps de Calvin, Droz, Genève.
König, A., 2002, God, waarom lyk die wêreld so? Kan ons sê: 'God is in beheer'?, Lux Verbi, Wellington.

Lactantius, 1973, 'Divinarum institutionum: De opificio Dei', in U. Boella (ed.), Patrologiae cursus completes, Collezione Classiche della Filosofia Cristiana, Firenze.

Lee, F.N., 2008, Calvin on law, Queensland Presbyterian Theological College, Brisbane.

Marsden, G.M., 2003, Jonathan Edwards: A life, Yale University Press, New Haven.

Origenes, 1836, De principiis: Primum separatim edidit et annotatione in usum academicum, Instruxit E.R. Redepenning, Bibliopolio Dykiano, Leipzig.

Schulze, L.F., 1971, Calvin's reply to Pighius, Pro Rege, Potchefstroom.

Vacant, A., Mangenot, E. \& Amann, E., 1935, Dictionnaire de théologie catholique, Letouzey \& Ané, Paris.

Van der Merwe, B., 2002, 'Kan 'n God van liefde soveel pyn toelaat?', Beeld, 08 Julie, p. 9. http://dx.doi.org/10.4102/ids.v36i4.524

Van der Molen, R.J., 1978, 'Providence as mystery, providence as revelation: Puritan and Anglican modifications of John Calvin's doctrine of providence', American Society of Church History 47(1), 29-47.

Van Wyk, J.H., 2002, 'Die mens wik maar God beskik? In gesprek met Adrio König oor sy eskatologiese, verbondsmatige voorsienigheidsleer', In die Skriflig/In Luce Verbi 36(4), 529-553. http://dx.doi.org/10.4102/ids.v36i4.524

Venema, C.P., 1986, 'Heinrich Bullinger's correspondence on Calvin's doctrine of predestination: 1551-1553', The Sixteenth Century Journal 17(4), 435-450. http:// dx.doi.org/10.2307/2541382 